\title{
The Effect of Financial Ratios Derived From Operating Cash Flows on Jordanian Commercial Banks Earnings per Share
}

\author{
Laith Abdel Rahman Abualrob ${ }^{1} \&$ Sanaa N. Maswadeh ${ }^{2}$ \\ ${ }^{1}$ Total Station, Amman, Jordan \\ ${ }^{2}$ Middle East University, Amman, Jordan \\ Correspondence: Sanaa N. Maswadeh, Professor of Accounting, Middle East University, Amman, Jordan. Tel: \\ 96-2796-745-498.
}

Received: November 4, 2019

Accepted: November 27, 2019

Online Published: December 2, 2019

doi:10.5430/ijfr.v11n1p394

URL: https://doi.org/10.5430/ijfr.v11n1p394

\begin{abstract}
This study tries to investigate the effect of operating cash flows ratios, which are (operating cash flows attributed to net income, operating cash flows attributed to credit facilities, and operating cash flows attributed to deposits) on earnings per share. The study was applied on Jordanian commercial banks listed on the Amman Stock Exchange during the period (2013-2017), and multiple regression analysis was used to test the study hypotheses.

The most important results revealed by the study were: the ratio of operating cash flows attributed to credit facilities is considered as the most important ratio derived from the cash flow statement helping in determining the earnings per share in Jordanian commercial banks. And there is a statistically significant effect of operating cash flows attributed to net income, operating cash flows attributed to credit facilities, and operating cash flows attributed to deposit on earnings per share in Jordanian commercial banks.
\end{abstract}

Keywords: Amman Stock Exchange, operating cash flows, earnings per share, net income, credit facilities, deposits

JEL Classification: G11, G21, M10

\section{Introduction}

The financial statements contain a large amount of accounting information relating to the previous and current financial periods. Therefore, it is not enough to prepare these statements, but they need to be analyzed using appropriate methods and tools to transform this data into useful information for making decisions and predicting the future of companies, then employing these analysis results to serve the purposes of various parties used accounting information.

The analysis using financial ratios is considered one of the most important financial analysis tools that many concerned parties have adopted in analyzing and studying the company's financial situation and making comparisons with other companies operating in the same or different sectors. The financial ratios derived from operating cash flows are important in determining the strengths and weaknesses of the company's business, assessing the company's liquidity and financing policies and predicting future cash flows (Matar, 2016).

The decisions related to cash flows and activities generated them, are among strategic decisions that have a clear effect on the company's earnings on the one hand and the decisions of investors and shareholders on the other hand. The development of the share price in the financial market is one of the objectives that the company's management seeks to achieve in which its profitability is reflected in the earnings per share which is an indicator of overall company performance. It is a reliable indicator to judge the success or failure of the company in achieving its objectives. For investors, identifying the most important indicators that control share prices is considered as an important source of information and thus helps them in making precise investment decisions. Also, the relationship between the share price in previous and later periods depends on many factors including earnings per share (Matar, 2016). Accordingly, this study came to examine the effect of financial ratios derived from operating cash flows on the Jordanian commercial bank's earnings per share. 


\subsection{Study Problem}

Commercial banks, like other companies, aim to make profits, so, naturally, banks' profits are achieved through the size of credit facilities granted to others, but their flexibility to grant credit facilities depends on the amount of liquidity available which depends on the bank's ability to generate cash flows, especially operating ones. Thus, the question remains regarding the amount of operating cash flows that enable banks to meet their commitments and their ability to face expected and unexpected withdrawal of deposits especially current deposits, also not rejected credit facilities covered by sufficient guarantees and through them banks can achieve financial earnings that are reflected in their profits and earnings per share which is an important financial performance indicator for current shareholders and prospective investors. Therefore, this study has been conducted to examine the following key question: - Is there a statistically significant effect of financial ratios derived from operating cash flows attributable to- net income, credit facilities, and deposits- on earnings per share?

\subsection{The Significant of the Study}

The analysis of cash flows has great importance for business entities due to its important role played in the planning process, making decisions related to those entities and assisting the management in determining the suitability and adequacy of operating cash flows to the company's needs. Also, it helps in providing necessary information about the company's operating cash flow activities, and assessing the success of operating policies and verifying effectiveness. Cash flows are providing an important indicator for earnings stability in future periods as well as their significance in providing predictability for company continuity or failure.

The lenders are concerned with operating cash flows which make them feel secure while financing companies that generate earnings and cash flows enable them to pay principles and interest on debts. Moreover, financial analysts and investors are also interested in operating cash flows, especially as most of the indicators and analytical models proposed in predicting the quality of earnings such as -Jones and Richardson- models depend on the value of operating cash flows calculated on a cash basis rather than on net earnings calculated on an accrual basis.

\subsection{Contribution of the Study}

This study is expected to contribute to the enrichment of scientific literature through an analytical study on the reality of cash flows as most of the previous studies relied on accounting earnings to measure financial performance. Therefore, this study is complementary to the previous studies to find out the effect of operating cash flows on earnings per share of Jordanian commercial banks through studying new ratios, such as operating cash flows attributable to credit facilities as well as operating cash flows attributable to deposits in Jordanian commercial banks in order to find out a model by which the most significant ratios derived from operating cash flows that affect earnings per share can be identified. This study is also a pioneer in terms of dealing with the environment of Jordanian commercial banks which is different from other environments especially as banks have a significant role in increasing the rates of development in the society by affording tremendous funding sources that support various branches of countries economics through the interaction of mechanisms and tools used to activate their tasks and increase welfare of communities. It is expected that the results, proposals, and recommendations of this study will help decision-makers, including companies' management, investors, financial analysts, and official authorities to know the effect of financial ratios derived from operating cash flows of commercial banks on earnings per share which reflected on share prices and the prosperity of financial market and national economy. It is hoped that this study will represent an important frame of reference for future studies to address the study subject from different aspects and new variables not addressed in this study, in addition to the possibility of reaching new results based on recent data.

\subsection{Study Hypotheses}

Based on the problem of the study, the study will test the following hypotheses:

The first hypothesis, $\mathrm{HO}_{1}$ : There is no significant effect at the level $(\alpha \leq 0.05)$ of -operating cash flows attributable to the net income- on the earnings per share of Jordanian commercial banks.

The second hypothesis, $\mathrm{HO}_{2}$ : There is no significant effect at the level $(\alpha \leq 0.05)$ of -operating cash flows attributed to credit facilities- on earnings per share of Jordanian commercial banks.

The third hypothesis, $\mathrm{HO}_{3}$ : There is no significant effect at the level $(\alpha \leq 0.05)$ of -operating cash flows attributable to deposits- on earnings per share of Jordanian commercial banks.

Hypotheses can be explained in the study model as follows: 


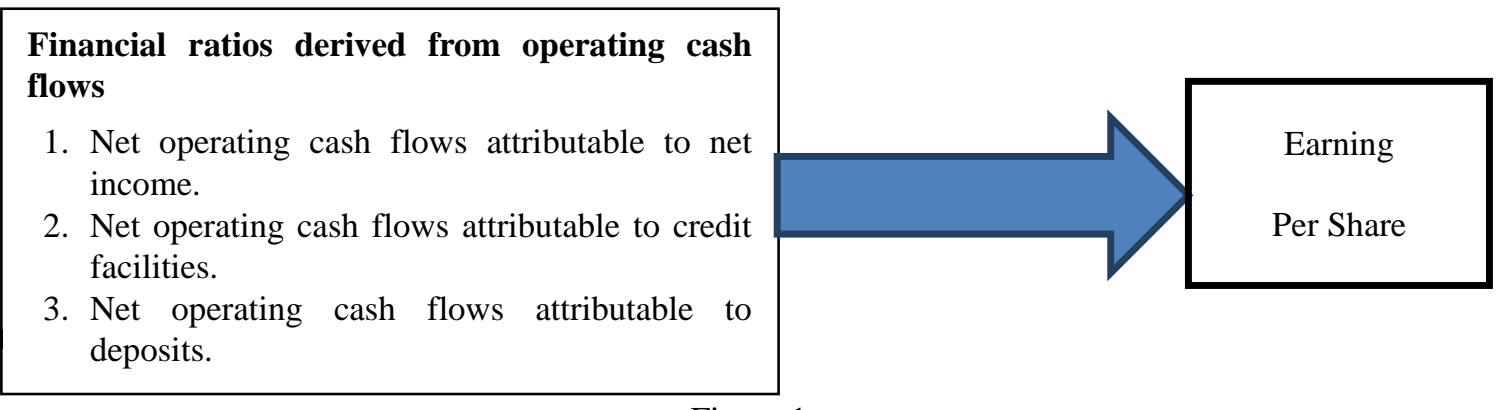

Figure 1

Source: Prepared by researchers

\section{Literature Review}

The cash flow statement can be relied on for financial analysis for its advantages, especially about the actual liquidity situation of the company, which may help to measure the company's ability to meet its commitments. The cash flows are important for banking sectors more than other sectors as they are inputs and outputs of banking operations, which requires providing information about cash transactions, activities, how to provide facilities to customers and the extent of change in its balances between the beginning and end of the financial period.

Cash flow statements include cash receipts and cash payments of the Company over a given period. Standard (7) classifies cash flows into flows from operating activities, flows from investment activities and flows from financing activities (Abu Nassar and Hamidat, 2014). The cash flow statement serves as an indicator of cash inflows, outflows, and timing in addition to the guarantee factor of future cash flows (Matar, 2016).

Samad, (2012) mentioned that credit facilities are considered one of the most important and risk functions of commercial banks as the safety of assets as well as the strength and durability of the financial situation depends heavily on them. The mechanism of bank credit is determined by policies and instructions set by bank management in addition to policies and instructions set by the Central Bank. If the deposits are the main source of funds in commercial banks, the credit provided by the bank to its customers, whether in the form of direct loans or credit facilities, is the use of these deposits. (Abu Kamal, 2012) defined credit facilities as a mechanism whereby the bank finances the customer whether a person or a company by giving him/her a direct loan or in the form of a credit facility or overdraft. Bank credit can be defined as the trust that the bank gives to the customer when putting at his/her disposal an amount of money, or guarantees for a certain period agreed upon between the two parties, then at the end of the period the borrower fulfills his/her commitment with a certain earning received by the bank represented in interests and commissions (Maitah et al., 2012). Credit facilities take the following forms (Maitah et al., 2012): debit current accounts, short-term loans, long-term loans and letters of guarantee (bank guarantees). Accordingly, the researcher has studied "operating cash flows attributable to credit facilities which measure net operating cash flows available to Jordanian commercial banks during a certain period from credit facilities.

Deposits are considered as one of the most important commercial bank's sources for financing. Therefore, banks are keen to develop them through developing banking and savings awareness by expanding services via opening more branches, simplifying the procedures of dealing in terms of withdrawal, in addition to issue various commercial papers that are accepted as a means of payment and endorsement, which lead to open a wide range of opportunities in this sector. According to (Bellucci, 2010), deposits are defined as the amounts of cash that individuals and entities temporarily place in the bank for a short or long term period to save them. (Shehadeh, 2017) defined deposit as what is deposited in a commercial bank, whether in the form of cash or checks from individuals, companies, and entities in their account to obtain a certain interest determined by the bank or under instructions issued by the Central Bank. The types of deposits offered by depositors in commercial banks are divided into demand deposits, term deposits and deposits with prior notification, in case the customers desire to withdraw them by a certain time (Al Hilali, 2017). Hence, this study investigated the ratio of "operating cash flows attributable to deposits", which measures the percentage of net operating cash flows generated by Jordanian commercial banks during a specified period from total deposits.

(Sekirifa, 2017 ) defined earnings per share as a set of earnings (profits) or losses from shares ( stock) investments over a specified period often a fiscal year which means earnings per share results in increasing owner's wealth. (Fakroun, 2015) believes that earnings per share are an important indicator of share real value because it shows how 
much earnings a company has after each tax deduction and in a way that the higher the earnings per share, the better the company's performance indicator will be. (Dergham, 2010) examined the correlation between the cash flows from the operating, investment and financing activities combined with the earnings pare shares in(7) of national banks operating in Palestine during the period 2000-2006. The results of the study showed a positive correlation between both the cash flows from operating activities and the cash flows from financing activities and the earnings of shares and it was found a negative correlation between the cash flows from investment activities and the earnings of shares. The study of (Hashem, 2011) aimed at determining the effect of operating cash flows attributable to sources of funding, namely short, long-term liabilities, and equity on the shares market value of industrial companies listed on the Libyan Stock Exchange during the period (2002-2009). The results of the study showed that operating cash flows ratios have a clear effect on share prices and hence on the value of the company, as well as the use of operating cash flows ratios by investors, financial analysts and decision-makers in the financial evaluation process helps them to have correct evaluation results. (Sulaimani, 2013) the study sought to indicate the effect of net operating cash flows attributable to the net income in all companies listed on the Kuwait Stock Exchange during the period between (2009-2012). The results of the study showed that there is no significant effect of operating cash flows on the profitability of companies listed on the Kuwait Stock Exchange. (Al-Saadi's, 2014) the study aimed at verifying the effect of cash flow ratios which is (cash-to-short-term liabilities, cash-to-equity ratio, and cash-to-sales ratio) on the market value of Iraqi companies listed on the Iraq Stock Exchange during the period (2006-2010).The results of the study showed that there is no significant effect on cash flow ratios studied on the market value of the share. The study of (Hamidi, 2014) sought to clarify the importance of using cash flow ratios attributable to certain financial statements elements (operating cash flows attributable to net income, operating cash flows attributable to sales, operating cash flows attributable to total assets, operating cash flows attributable to short-term liabilities and cash flows attributable to equity) and to show their effect as independent variables on the value of the company measured by (market value to book value ratio) as a dependent variable, in commercial banks listed on the Iraq Stock Exchange during the period 2008-2012. The results showed that there is a significant effect of operating cash flows attributable to sales, net income and total assets on the value of the company, while the operating cash flows attributable to short-term liabilities and equity had no significant effect on the value of the company.

The study of (Martani et al., 2009) aimed at investigating the effect of operating cash flows attributable to net income and the effect of operating cash flows attributable to sales on the earnings per share of (21) industrial companies listed on the Indonesia Stock Exchange during the period 2003-2006.The results of the study showed that there is a significant effect of the operating cash flows attributable to net income, on earnings per share while there is no significant effect of operating cash flows attributable to sales on the earnings per share. (Taani, 2011) examined the effect of the operating cash flows attributable to net income, and operating cash flows attributed to total assets on the earnings per share for a sample of (40) industrial companies listed on the Amman Stock Exchange during the period between (2000-2009), the study results showed that there is a significant effect of both the ratio of operating cash flows attributable to net income and the ratio of cash flows attributed to total assets on the earning per share. (Owolabi\& Obida, 2012) examined the effect of operating cash flows attributable to current liabilities on the profitability measures by (earnings per share and returns on assets) for a study sample consisting of (12) industrial companies listed on the Nigeria Stock Exchange during the period. (2005-2009). The results of the study showed that there is a significant effect of the operating cash flow attributable to the current liabilities on the company's studied profitability measures by (earning per share and return on assets). The study of (Pouraghajan et al., 2013) examined the effect of operating cash flows and the size of the company on the earnings per share of (140) companies listed on the Tehran Stock Exchange during the period (2006-2010), The results of the study showed that there is no significant effect of operating cash flows on earnings per share. The study of (Eyisi\& Okpe, 2014) investigated the effect of operating cash flows attributed to total assets and operating cash flows attributable to total liabilities on the performance of (35) companies listed on the Nigeria Stock Exchange during the period (2009-2013). The results of the study showed that there is a significant effect of both operating cash flows attributable to total assets and operating cash flows attributable to total liabilities on the financial performance measured by earnings per share. The study of (Khanji\& Siam, 2015) examined the effect of operating, investment and financing cash flow on the shares market value of (13) commercial banks listed on the Amman Stock Exchange during the period 2010-2013. The results of the study showed a significant positive effect of all operating, financing and investment cash flows on the shares market value.(Etale\& Bingilar, 2016) examined the effect of financial ratios including operating cash flows attributable to the average number of shares, operating cash flows attributable to total assets, and cash dividends attributable to operating cash flows on the stock price of (10) Commercial banks listed on the Nigeria Stock Exchange during the period (2005-2014). The results of the study showed a positive effect of both operating cash flows attributable to the average number of shares and operating cash flows attributable to total assets and cash 
dividends attributable to operating cash flows on the stock price. The study of (Soewignyo\& Soewignyo, 2017) aimed at investigating the effect of a set of financial ratios, namely: the ratio of operating cash flows attributable to total liabilities, and the ratio of operating cash flows attributable to current liabilities on the company's performance measured by (earnings per share, returns on assets and returns on equity) for the sample of (40) companies listed on the Indonesia Stock Exchange during the period (2010-2016). The study showed that there is a significant effect of both the operating cash flows attributable to the total liabilities and the operating cash flows attributable to the current liabilities on the profitability of the company in all its indicators (earnings per share, return on assets and return on equity). The study of (Oroud et al., 2017) sought to investigate the effect of operating, investment and financing cash flow on the shares market prices of (13) commercial banks listed on the Amman Stock Exchange during the period (2000-2015). The results of the study showed a significant positive effect of both operating and financing cash flows on the shares market prices, whereas there is a significant negative effect of investment cash flows on the shares market prices.

\section{Methodology and Data Analysis}

This section includes a description of the method and procedures used in the study. It also includes a definition of the study population and sample, sources of data collection, variables, methods of measurement and statistical methods to test hypotheses. In this study, the researchers have used the descriptive analytical approach based on an analytical study of the actual financial statements published in financial statements and annual reports issued by the banks included in the study during the specified period of 2013-2017.

Also, we will validate the variables data for statistical analysis by using the normal distribution test of the study model variables in addition to studying the linear interference between independent variables using (Multicollinearity Test). Finally, the study hypotheses will be tested based on the multiple regression models.

\subsection{Population and Sample of the Study}

The study population consists of 16 commercial banks in Jordan whose shares are listed and traded on the Amman Stock Exchange. The study sample consists of the entire population of Jordanian commercial banks.

\subsection{Sources of Data Collection}

To achieve study objectives, enrich its theoretical framework and test its hypotheses, reference has been made to library resources such as books, periodicals, conferences, master theses and doctoral theses to clarify the studies that dealt with study subject and considered its results. Reference has been also made to the annual reports of Jordanian banks to obtain necessary data for the independent and dependent study variables for the period (2013 - 2017).

\subsection{Statistical Methods Used in Data Analysis}

Several tests have been used so that each test fits with the purpose for which it is used. The following tests are given: Descriptive statistics to indicate the characteristics of study variables. The arithmetic mean has been used as a measure of central tendency and the maximum and the minimum value. Also, the standard deviation has been used as a measure of data dispersion from its mean. Regarding the normality distribution of the data, the Kolmogorov-Smirnov test has been used. Multicollinearity test has also been used where Variance Inflationary Factor has been based on to verify the absence of linear interference between the independent variables of the study. The multiple regression tests were used to test the hypotheses of the study by using this study model:

$$
\mathrm{EPS}_{\mathrm{i}-\mathrm{t}}=\beta_{0 \mathrm{i}-\mathrm{t}}+\beta_{1} * \mathrm{X} 1_{\mathrm{i}-\mathrm{t}}+\beta_{2} * \mathrm{X} 2_{\mathrm{i}-\mathrm{t}}+\beta_{3} * \mathrm{X} 3_{-\mathrm{t}}+\varepsilon_{\mathrm{i}-\mathrm{t}}
$$

- X1: Operating cash flows attributable to net Income: they are calculated by dividing net operating cash flows / net income.

- X2: Operating cash flows attributable to credit facilities: they are calculated by dividing net operating cash flows/credit facilities

- X3: Operating cash flows attributable to deposits: they are calculated by dividing net operating cash flows/deposits EPS $_{i-t}$ : EPS is calculated by the following equation:

(Net Income After Tax -Dividends of prefers stocks/ weighted average of outstanding common stocks

- i-t Company (i) in the year (t).

- $\varepsilon_{\mathrm{i}-t}=$ regression error.

- $\beta_{0}=$ equation constant

- $\beta_{1}: \beta_{2}: \beta_{3}$ : Regression coefficients for independent variables. 


\subsection{Descriptive Statistics of the Study and Its Variables}

A descriptive analysis of financial ratios derived from the operating cash flows has been conducted in addition to the descriptive analysis of earnings per share as shown in the following Table 1.

Table 1. Descriptive analysis test

\begin{tabular}{lllll}
\hline Study variables & mean & Standard division & Minimum value & Maximum value \\
\hline $\begin{array}{l}\text { Net operating cash flows attributable } \\
\text { to net income. }\end{array}$ & 0.613 & 3.569 & -7.20 & 7.38 \\
\hline $\begin{array}{l}\text { Net operating cash flows attributable } \\
\text { to credit facilities. }\end{array}$ & 0.032 & 0.157 & -0.23 & 0.94 \\
\hline $\begin{array}{l}\text { Net operating cash flows attributable } \\
\text { to deposits }\end{array}$ & 0.020 & 0.083 & -0.19 & 0.25 \\
\hline Earnings Per Share & 0.203 & 0.126 & 0.01 & 0.49 \\
\hline
\end{tabular}

Table 1 shows the arithmetic mean, the standard deviation, and the maximum and minimum values of the independent study variables, namely: (operating cash flows attributable to net income, operating cash flows attributed to credit facilities, and operating cash flows attributable to deposits) as independent variables in addition to the dependent variable of earnings per share.

\subsection{Data Validation Tests}

It is necessary to make sure that the data of the study follows the conditions that ensure the variables are appropriate for statistical analysis. The data validation tests are presented in the form of normality of residuals test and linear interference test where the Kolmogorov-Smirnov test has been used to test the normality distribution of data as shown in Figure 2.

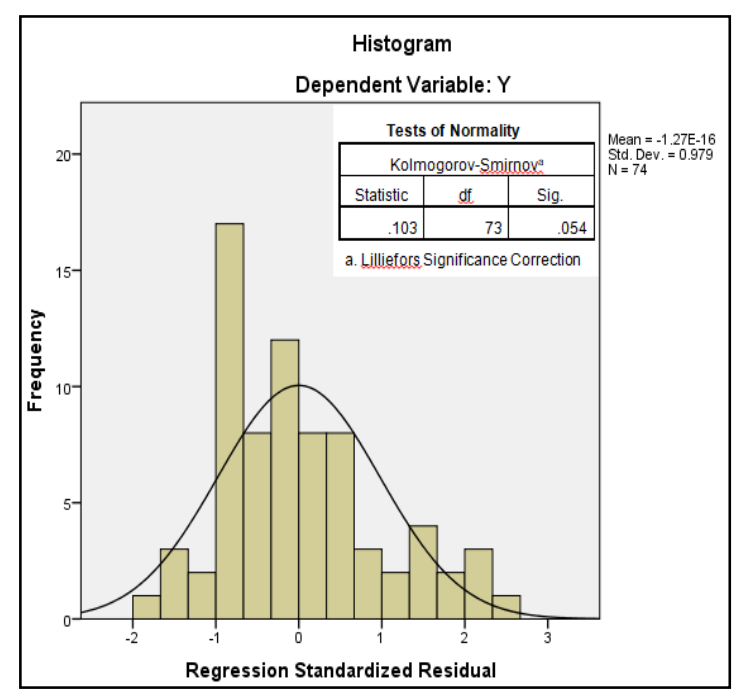

Figure 2. Normal distribution of the residuals of the regression model

Source: Statistical Analysis Results (SPSS)

Figure 2 shows the results of checking the normality distribution of the residuals of the study model where the normality distribution test (Kolmogorov-Smirnov) has been used at a confidence level (95\%). The results of the test showed that the residuals of the study model are moderate and follow the normality distribution because the probability value (P-Value) is higher than (5\%) (Hayduk et al., 2007). As a result, the study variables have been 
validated to use in the multiple regression model to show the effect of financial ratios derived from operating cash flows on the earnings per share of listed Jordanian commercial banks in the Amman Stock Exchange.

The Multicollinearity test was used to verify the absence of linear interference between the independent study variables. As well as, Variance Inflationary Factor (VIF) and Tolerance indicator were used as shown in Table 2 as follows:

Table 2. Multicollinearity test

\begin{tabular}{lll}
\hline Study variables & VIF & Tolerance \\
\hline Net operating cash flows attributable to net income. & 1.319 & 0.758 \\
\hline Net operating cash flows attributable to credit facilities. & 3.967 & 0.252 \\
\hline Net operating cash flows attributable to deposits & 3.705 & 0.270 \\
\hline
\end{tabular}

Source: Statistical Analysis Results (SPSS)

Variance inflationary values (VIF) are based on to detect linear multiplicity. According to the general rule of VIF, there is linear multicollinearity when its value is higher than (5). For tolerance test, the problem of multicollinearity appears in case that tolerance coefficient is lower than $(0.20)$, where it leads to incorrectly amplify the effect of the independent variables in regression due to increased inflation among them (Luo et al., 2007). When reviewing Table (2) concerning the variance inflationary factor, it is found that all (VIF)values of independent variables are less than (5) and all tolerance values are higher than (0.20). Thus, it is clear that all independent study variables passed these tests successfully which means that there is no problem of linear interference and autocorrelations between independent variables in the study model.

\subsection{Testing the Study Hypotheses}

To test the study hypotheses, it has been based on the multiple regression test, the results of which are shown in Table 3 as follows:

Table 3. Multiple regression analysis

Study Model: $\mathrm{EPS}_{\mathrm{i}-\mathrm{t}}=\beta_{0 \mathrm{i}-\mathrm{t}}+\beta_{1} * \mathrm{X} 1_{\mathrm{i}-\mathrm{t}}+\beta_{2} * \mathrm{X} 2_{\mathrm{i}-\mathrm{t}}+\beta_{3} * \mathrm{X} 3_{-\mathrm{t}}+\varepsilon_{\mathrm{i}-\mathrm{t}}$

\begin{tabular}{|c|c|c|c|c|}
\hline Study variables & Coefficient & T-Statistic & $\boldsymbol{\beta}$ & Prob. (T-statistic) \\
\hline Constant & --------- & 15.511 & 0.233 & 0.000 \\
\hline Net operating cash flows attributable to net income. & 0.256 & 2.023 & 0.002 & 0.047 \\
\hline $\begin{array}{l}\text { Net operating cash flows attributable to cred } \\
\text { facilities. }\end{array}$ & ${ }^{i^{2}} 0.674$ & 3.072 & 0.476 & 0.003 \\
\hline Net operating cash flows attributable to deposits & 0.598 & 2.821 & 0.445 & 0.006 \\
\hline $\mathrm{R}=0.489$ & \multicolumn{4}{|c|}{$\mathrm{R}^{2}=0.252$} \\
\hline Adjusted $\mathrm{R}^{2}=0.215$ & & \multicolumn{3}{|c|}{ F-statistic $=4.172$} \\
\hline Prob.(F-statistic) $=0.009$ & & & & \\
\hline
\end{tabular}

Source: Statistical Analysis Results (SPSS)

Table 3 shows the results of the multiple regression test of the independent study variables represented by the financial ratios derived from the operating cash flows combined (operating cash flows attributable to net income, operating cash flows attributed to credit facilities, and operating cash flows attributed to deposits) and their effect on earnings per share as a dependent variable. It is noticed from Table 3 that the F-calculated value is (4.174) at a confidence level (95\%). Probability value of (F-statistic) is (0.009) which is less than Significant level $(\alpha \leq 0.05)$ indicating that the study model is statistically suitable and proven that there is a statistically significant effect on the financial ratios derived from the operating cash flows combined (operating cash flows attributable to net income, 
operating cash flows attributable to credit facilities and operating cash flows attributable to deposits) on earnings per share in Jordanian commercial banks. The results of the multiple regression analysis shows that the value of the adjusted explanation coefficient (Adjusted- $\mathrm{R}^{2}$ ) is $(0.215)$ which means that the changes in earnings per share by $(21.5 \%)$ can be explained through the financial ratios derived from operating cash flows (combined) represented by (operating cash flows attributable to net income, operating cash flows attributable to credit facilities, and operating cash flows attributable to deposits. The researchers believe that, in addition to operating cash flows resulting from operating activities, there are many different factors affecting earnings per share resulting from other non-operating activities that affect earnings per share in the banking sector. In addition to the market factors, economic conditions and local and political policies have an effect on earnings per share in the banking sector which has a different business nature than other sectors. This result is similar to the study result of (Etale\& Bingilar, 2016) where it found that there is an effect of a set of ratios derived from the operating cash flows on earnings per share in commercial banks listed on the Nigeria Stock Exchange. Similarly to the study of (Dergham, 2010), it showed a positive correlation between operating cash flows and earnings per shares of Palestine national banks. These results are different from (Sulaimani's, 2013) study which showed no significant effect of operating cash flows on the profitability of listed companies in Kuwait Stock Exchange, relying on the questionnaire as a study tool. These results are also different from (Pouraghajan, et al., 2013) study which has been applied to listed companies in the Tehran Stock Exchange where it concluded that there is no effect of operating cash flows on earnings per share.

The results of the regression analysis in Table 3 show that the value of Prob. (T-statistic) of operating cash flows variable attributable to net income is (0.047), at a confidence level of $(95 \%)$. According to the rule which provides a statistically significant effect when the value of Prob. (T-statistic) is less than $(\alpha \leq 0.05)$, therefore, earnings per share are affected by operating cash flows attributable to the net income in Jordanian commercial banks. The coefficient value (0.256) indicates that the operating cash flows attributable to the net income have a positive effect on earnings per share of the Jordanian commercial banks. Accordingly, the alternative hypothesis is accepted which states that "there is a statistically significant effect at $(\alpha \leq 0.05)$ of operating cash flows attributable to the net income on earnings per share of Jordanian commercial banks". The researchers believe that this result is expected as the income comes from operating-activities. The greater the expected income, the greater part of which is expected to be operating cash flows especially since operating cash flows are more real than income calculated on an accrual basis. So, there is a positive effect on the earnings of shares to these banks. This result is similar to the study of (Hamidi, 2014) which found the effect of cash flows attributable to net income on the value of banks listed on the Iraq Stock Exchange. It also similar to the study of (Taani, 2011), which found an effect of operating cash flows attributable to net income on the share earnings of industrial companies listed on the Amman Stock Exchange, in addition to (Martani et al., 2009) study which found that there is an effect of cash flows attributable to net income on the earnings per share of industrial companies listed on the Indonesia Stock Exchange.

Also, Table 3 shows it is clear from the results of regression analysis that the value of Prob. (T-statistic) for the variable of operating cash flows attributable to the credit, facilities are (0.003) at a confidence level (95\%). According to the rule which provides a statistically significant effect when the value of Prob. (T-statistic) is less than $(\alpha \leq 0.05)$, therefore, earnings per share are affected by the operating cash flows attributable to credit facilities of Jordanian commercial banks. The coefficient value is (0.674) which indicates that the operating cash flows attributable to credit facilities affect positively earnings per share of Jordanian commercial banks. The value of this coefficient indicates that the operating cash flows attributable to credit facilities are the most influential factors in determining the earnings per share of the Jordanian commercial banks among other financial ratios derived from the operating cash flows dealt with in this study as shown in Table 3. Accordingly, the alternative hypothesis which states that "there is a statistically significant effect at the level $(\alpha \leq 0.05)$, of operating cash flows attributable to credit facilities on the earnings per share of Jordanian commercial banks is accepted". The researchers explain the reason is that credit facilities are one of the main operating activities carried out by commercial banks which is profitable to commercial banks through the earnings derived from them. Therefore, there is a positive effect on the bank's ability to achieve earnings resulting on earnings per share through optimal and sufficient use of its resources in granting credit facilities which constitutes a significant percentage of the Bank's assets that are used for generating earnings with paying emphasis on the Bank's ability to meet its liabilities. This result is similar to (Etale\& Bingilar, 2016) study result which found that there is an effect of operating cash flows attributable to total assets on earnings per share of banks listed on the Nigeria Stock Exchange and (Eyisi\& Okpe, 2014) found a positive impact of operating cash flows attributable to total assets on the financial performance measured by earnings per share of listed companies on the Nigeria Stock Exchange and also it is similar to the study of (Taani, 2011) which found that there 
is a positive effect of cash flows attributable to total assets on earnings per share of companies listed on the Amman Stock Exchange.

Referring to Table 3, it is shown that the value of Prob. (T-statistic) of the variable of operating cash flows attributable to deposits is (0.006), at confidence level \%95. According to the rule which provides a statistically significant effect when the value of Prob. (T-statistic) is less than $(\alpha \leq 0.05)$ therefore, earnings per share are affected by operating cash flows attributable to deposits of Jordanian commercial banks. The Coefficient value (0.598) indicates that the operating cash flow attributable to deposits positively affects earnings per share of Jordanian commercial banks. Accordingly, the alternative hypothesis which states that "there is a statistically significant effect at the level $(\alpha \leq 0.05)$, of operating cash flows attributable to deposits on the earnings per share in Jordanian commercial banks, is accepted". The researchers concur with this result, especially that Jordanian commercial banks rely on deposits to perform its tasks through providing credit facilities through which they achieve the credit interests that enable the bank to meet the commitments of these deposits and earn profits that enhance the earnings per share. This result is similar to (Soewignyo\& Soewignyo's, 2017) study applied in Indonesia and (Eyisi\& Okpe's, 2014) study applied in Nigeria where both studies found a positive effect of operating cash flows attributable to total liabilities on earnings per share.

\section{Conclusion}

\subsection{Findings and Impressions of the Study}

The study reveals a set of results, most notably, that the highest positive effect on the earnings per shares of commercial banks is the operating cash flows attributed to credit facilities, followed by the positive effect of operating cash flows attributed to deposits and finally operating cash flows attributable to net income, especially the earnings figure is calculated on an accrual basis which is still facing a lot of criticism in the accounting thought. Therefore, researchers can conclude that the decision to grant credit is one of the most important decisions for which the bank's management is responsible and it is also one of the most important factors for the success of banks' performance within an acceptable level of risk. Then this is achieved by making a balance between the amount of cash deposited and the credit facilities, in other words, balancing must be made between cash inflows and cash outflows as well as the availability of liquidity in the bank are a necessity to continue providing credit facilities. Especially the main source of such liquidity is deposited.

The researchers confirmed on the light of the results revealed by the study, the importance of commercial bank management to the expansion in operating activity through the optimal use of deposits in the financing of credit facilities to increase earnings, which is expected to improve earnings per share. The researchers also, focused that profit figures, which consist with profits from unusual or non-recurring investment sources can be, deceived the decisions, if it take solely from the analysis of operating activities which provide information that can effectively contribute to determining earnings per share and making rational decisions. The researchers recommend Securities Commission Committee in Jordan to set the instructions binding commercial banks to calculate and publish financial ratios derived from operating cash flows especially the ratio of operating cash flows attributable to credit facilities, because of their significant effect on the earning per share and thus increases their ability to continue and be competent in local and global markets.

\subsection{Future Research}

The researchers recommended re-conducting the same study by testing different set of cash flow ratios derived from investment and financing operations and compare the effect of these ratios with cash flow ratios derived from operating activities and test their effect on other dependent variables, such as the earnings quality, market value and other financial indicator. Also further research may applied on companies within other sectors to show the effect of financial ratios derived from operating cash flows on the earning per share of those companies more thoroughly and compares the results between these sectors.

\subsection{Study Limitations}

This paper is applying in Jordanian commercial banks, so, the results of this study could be generalized to companies similar to those that were included in this study. Also, the study period limited in the years $(2013-2017)$ and not extending it further. Finally, there are few studies focus specifically on ratios derived from operating cash flows on commercial banks in Jordan and other countries. 


\section{Acknowledgment}

The authors are grateful to the Middle East University, Amman, Jordan for the financial support granted to cover the publication fee of this research article.

\section{References}

Abu Kamal, M. (2012). Modern Management of Credit Risk in Banks according to International Standards: An applied Study on Banks Operating in Palestine. Unpublished Master Thesis, Islamic University, Gaza.

Abu Nassar, M., \& Hamidat, J. (2014). International Accounting and Financial Reporting Standards: Cash Flows and Market Value of Shares. Journal of King Abdulaziz University of Economics and Management, 25(2), 23-39.

Al-Hilali, M. (2017). Financial Accounting, Second Edition. Dar Al-Manhaj for Publishing and Distribution, Amman, Jordan.

Al-Saadi, A. (2014). The Effect of Cash Flows on the Market Value of Iraqi Companies Listed in the Iraq Stock Exchange. Al-Qadisiya Journal for Administrative and Economic Sciences, 16(1), 137-148.

Al-Sulaimani, K. (2013). The Effect of Net Operating Cash Flow in Public Shareholding Companies in Kuwait on Their Profitability: An Empirical Study. Unpublished Master Thesis, Middle East University, Amman, Jordan.

Bellucci, A., Borisov, A., \& Zazzaro, A. (2010), Dose Gender Matter in Bank Firm Relationships? Evidence from Small Business Lending. Journal of Banking and Finance, 34(1), 2968-2984. https://doi.org/10.1016/j.jbankfin.2010.07.008

Dergham, M., \& Dergham, S. (2010). The Relationship between Cash Flows and Returns on Equity under International Accounting Standard No 7: An applied Study on National Banks Operating in Palestine. Arab Journal of Management, 30(2), 1-44.

Etale, L., \& Bingilar, P. (2016). The Impact of Cash Flow on Stock Price in the Banking Sector of Nigeria. Business, Management and Economics Research, 2(7), 136-140.

Eyisi, A., \& Okpe, I. (2014), The Impact of Cash Flow Ratio on Corporate Performance. Research Journal of Finance and Accounting, 5(6), 149-159.

Fakroun, A. (2015). The effect of the size of the listed economic institution on earnings per share. Unpublished Master Thesis, KasidiMerbah University, Ouargla, Algeria.

Hamidi, K. (2014). The effect of operating cash flows on the value of the company: an applied study of Iraqi private banks sample listed in Iraq Stock Exchange. Journal of Muthanna for Administrative and Economic Sciences, $3(7), 64-87$.

Hashim, F. (2011). The Effect of Operating Cash Flows on the Value of the Institution. Unpublished Master Thesis, Graduate Academy, Tripoli, Libya.

Hayduk, L., Cummings, G., Boadu, K., Pazderka-Robinson, H., \& Boulianne, S. (2007). Testing! Testing! One, Two, Three-Testing the Theory in Structural Equation Models!. Personality and Individual Differences, 42(5), 841-850. https://doi.org/10.1016/j.paid.2006.10.001

Khanji, I., \& Siam, A. (2015). The Effect of Cash Flow on Share Price of the Jordanian Commercial Banks Listed in Amman Stock Exchange. International Journal of Economics and Finance, 7(5), 109-118. https://doi.org/10.5539/ijef.v7n5p109

Luo, B., Groenke, K., Takors, R., Wandrey, C., \& Oldiges, M. (2007). Simultaneous Determination of Multiple Intracellular Metabolites in Glycolysis, Pentose Phosphate Pathway, and Tricarboxylic Acid Cycle by Liquid Chromatography-Mass Spectrometry. Journal of Chromatography A, 1147(2), 153-164. https://doi.org/10.1016/j.chroma.2007.02.034

Maitah, M., Zeda, K., \& Galalh, A. (2012). The Utilizing of Financial Analysis in Credit Decision in Palestinian Commercial Banks. Journal of Money, Investment and Banking, 24(12), 114-122.

Martani, D., Khairurizka, R., \& Khairurizka, R. (2009). The Effect of Financial Ratios, Firm Size, and Cash Flow from Operating Activities in the Interim Report to the Stock Return. Chinese Business Review, 8(6), 44-55.

Matar, M. (2016). Recent Trends in Financial and Credit Analysis: Methods, Tools and Practical Uses (4th ed.). Wa'el Publishing House, Amman, Jordan. 
Oroud, Y., Islam, M., \& Salha, T. (2017). The Effect of Cash Flows on the Share Price on the Amman Stock Exchange. American Based Research Journal, 6(7), 22-28.

Owolabi, S., \& Obida, S. (2012). Liquidity Management and Corporate Profitability: Case Study of Selected Manufacturing Companies Listed on the Nigerian Stock Exchange. Business Management Dynamics, 2(2), 10-25.

Pouraghajan, A., Mansourinia, E., Bagheri, S., Emamgholipour, M., \& Emamgholipour, B. (2013). Investigation the Effect of Financial Ratios, Operating Cash Flows and Firm Size on Earnings Per Share: Evidence from the Tehran Stock Exchange. International Research Journal of Applied and Basic Sciences, 4(5), 1026-1033. https://doi.org/10.5539/ijef.v4n7p41

Samad, A. (2012). Credit Risk Determinants of Bank Failure: Evidence from US Bank Failure. International Business Research, 5(9), 67-76. https://doi.org/10.5539/ibr.v5n9p10

Shehadeh, A. R. (2017). Accounting for Financial Institutions (2nd ed.). Dar Al-Manhaj for Publishing and Distribution, Amman, Jordan.

Skirifa, R. (2017). The Effect of Profitability, Liquidity and Activity Ratios on Earnings of Shares in Economic Sectors. Unpublished Master Thesis, KasidiMerbah University, Ouargla, Algeria.

Soewignyo, F., \& Soewignyo, T. (2017). Basic Industry and Chemicals Subsector Cash Flow Ratios and Profitability. Journal of US-China Public Administration, 14(6), 321-329. https://doi.org/10.17265/1548-6591/2017.06.003

Taani, K. (2011). The Effect of Financial Ratios, Firm Size and Cash Flows from Operating Activities on Earnings per Share: An Applied Study on the Jordanian Industrial Sector. International Journal of Social Sciences and Humanity Studies, 3(1), 197-205. 